Article

\title{
The Effect of Roasting on the Protein Profile and Antiradical Capacity of Flaxseed Meal
}

\author{
Katarzyna Waszkowiak ${ }^{1, *(-)}$ and Beata Mikołajczak ${ }^{2}$ (D) \\ 1 Department of Gastronomy Science and Functional Foods, Faculty of Food Science and Nutrition, \\ Poznan University of Life Sciences, Wojska Polskiego 31, 60-624 Poznań, Poland \\ 2 Department of Meat Technology, Poznan University of Life Sciences, Wojska Polskiego 31, 60-624 Poznań, \\ Poland; beata.mikolajczak@up.poznan.pl \\ * Correspondence: katarzyna.waszkowiak@up.poznan.pl; Tel.: +48-61-848-73-79
}

Received: 10 August 2020; Accepted: 27 September 2020; Published: 30 September 2020

\begin{abstract}
Roasting is more and more often used as a pre-treatment of flaxseeds. However, the process can influence flaxseed proteins that may be crucial for their properties. The aim of this research was to study changes in the electrophoretic protein profile (SDS-PAGE) and the antiradical capacity of flaxseed meals after roasting. The roasting temperature $\left(160,180\right.$, and $\left.200^{\circ} \mathrm{C}\right)$ and flaxseed cultivars (golden and brown seed) were factors including in the study. The free (F-MRP) and bound-to-protein (B-MRP) Maillard reaction products were also analyzed. The most significant changes in the SDS-PAGE protein profiles of roasted seeds of each of the tested flax cultivars were observed for the $13 \mathrm{kDa}$ protein fraction (decrease) and for the $19 \mathrm{kDa}$ and $17 \mathrm{kDa}$ fractions (increase). The research revealed a significant correlation between the roasting temperature and B-MRP content, and changes in the percentage share of those three protein fractions. The antiradical capacity of roasted flaxseeds decreased, as compared with untreated seeds. After roasting at $200{ }^{\circ} \mathrm{C}$ the antiradical capacity of flaxseeds improved slightly, probably due to the MRP formation, but it was still significantly lower than that of the raw seeds. The research provides novel information about key protein fractions that seem to be important changing during heat treatment.
\end{abstract}

Keywords: flaxseed; defatted meal; roasting; SDS-PAGE protein profile; antioxidative capacity; Maillard reaction product

\section{Introduction}

Since ancient times, flaxseeds (Linum usitatissimum L.) have been included in the diet of humans and animals. The health benefits of flaxseeds are mostly attributed to the content of compounds such as $\alpha$-linolenic fatty acid, lignan secoisolariciresinol, and insoluble and soluble dietary fiber [1]. However, flaxseeds and flaxseed cakes are also a valuable source of protein [2,3]. The crude protein content $(\mathrm{N} \times 6.5)$ amounts to about $35-45 \%$ of the dry oil-free mass of flaxseeds [2]. The amino acid profile, digestibility, and biological value of flaxseed proteins have been reported to be comparable to soy proteins [4]. Flaxseed proteins are usually divided into high and low molecular weight (MW) fractions [5]. The major high MW fraction of flaxseed protein, often termed as linin (its MW estimated with various analytical methods is $252-320 \mathrm{kDa}$ ), amounts to about $58-66 \%$ of total flaxseed proteins [6,7]. Linin has 11-12 S globular structure consisting of five unidentical polypeptide subunits with MWs of $14.4 \mathrm{kDa}, 24.6 \mathrm{kDa}, 30.0 \mathrm{kDa}, 35.3 \mathrm{kDa}$, and 50.9 kDa (SDS-PAGE MW distribution) [7]. The major low MW component of flaxseed protein is called conlinin. It is a $2 \mathrm{~S}$ albumin-type structure consisting of a single polypeptide chain (15-17 kDa), which makes $20-42 \%$ of the total flaxseed proteins [2,6]. The $2 \mathrm{~S}$ proteins are water-soluble (about 93\%) due to their small size [8]. Other low MW structural and physiological proteins (e.g., oleosin, hirudin) were also found in flaxseeds [2]. 
Flaxseed protein is an interesting source of unique peptides and proteins. Some of them are endogenous, e.g., 0.9-1.1 kDa cyclolinopeptides [9], $7 \mathrm{kDa}$ lunasin-like peptide [10], and $25 \mathrm{kDa}$ linusitin [11], while others are products of hydrolysis [12]. They exhibit anti-inflammatory, hypotensive, immunosuppressive, and anti-fungal properties [12-14]. Flaxseed proteins and peptides also exhibit various functional properties, e.g., water and fat absorption, emulsification, and foaming capacity [3,15], which are important in the food industry. These properties of flaxseed proteins recently encourage researchers to focuses on methods of efficient extraction and isolation $[16,17]$. The influence of various processes on modification and improvement of functional properties of flax proteins was also investigated. Yu et al. [18] considered atmospheric pressure plasma jet as an effective strategy to improve the functionality (foaming and emulsifying properties) and antioxidant activities of flaxseed protein. Juodeikiene et al. [19] used high-frequency ultrasound for the flaxseed protein functionalization, and they found that functional properties of proteins (emulsifying, foaming, and gelling) significantly depended on the medium $\mathrm{pH}$ and ultrasound intensity. The properties of flaxseed proteins also cause more and more frequent attempts to use them in food production (e.g., bread, gluten-free products, and meat products) [20-22].

Roasting is more and more often used as a pre-treatment of flaxseeds when they are to be used as a food ingredient [23] because it improves their flavour. It also significantly reduces the cyanogenic glycoside content in flaxseeds [24]. The process alters the cellular structures of seeds and increases their capacity to be broken up by chewing [25]. Moreover, heating before cold-pressing of oilseeds generally increases oils yield [26]. On the other hand, roasting damages the cell structure [27] and increases the sensitivity of valuable flaxseed compounds to changes induced by thermal treatment [28-31]. An earlier study by Waszkowiak, Siger et al. [28] showed that the roasting of flaxseeds at a temperature of $160-220^{\circ} \mathrm{C}$ considerably influenced the nutritional quality of flaxseed oil (e.g., the content of total tocopherol decreased, but the content of plastochromanol-8 increased) and deteriorated its oxidative stability. Other studies $[29,30]$ revealed changes in the percentage share of individual protein fractions in the protein profiles of roasted (in the ranges of $160-200{ }^{\circ} \mathrm{C}$ and $\left.8-24 \mathrm{~min}\right)$ and steamed $\left(100{ }^{\circ} \mathrm{C}\right.$, $16 \mathrm{~min}$ ) flaxseeds. However, the differences between the cultivars were not assessed in these studies. Changes in the protein fractions may be caused by both protein structural changes and their interactions with other seed compounds (e.g., as a result of the formation of Maillard reaction products). It may be crucial for the nutritional value and functional properties of flaxseed proteins. So far, there has been no comprehensive study showing the effect of both roasting temperature and cultivar on changes in the protein profile as well as the antioxidative capacity of flaxseed meals.

The aim of the research was to study changes in the electrophoretic protein profile (SDS-PAGE) and antiradical capacity (oxygen radical absorbance capacity assay with fluorescein as a fluorescent probe-ORAC_FL assay) of flaxseed meals after roasting. The roasting temperature $\left(160,180\right.$, and $\left.200^{\circ} \mathrm{C}\right)$ and flaxseed cultivars (golden and brown seed) were factors including in the study. The free (F-MRP) and bound-to-protein (B-MRP) Maillard reaction products were also analyzed.

\section{Materials and Methods}

\subsection{Materials}

The research materials were flaxseeds (Linum usitatissimum L.) of three cultivars: golden seed Jantarol, Oliwin, and brown seed Szafir (IHAR, Borowo, Poland; year of production: 2017). The seeds were stored in jute bags at room temperature. The moisture, protein and fat contents of raw seeds (Table S1) were $69.7 \pm 0.3,220.9 \pm 8.7$ and $386.4 \pm 0.7 \mathrm{~g} / \mathrm{kg}$ for Szafir cultivar; $58.2 \pm 8.7,213.7 \pm 0.7$, and $400.1 \pm 1.1 \mathrm{~g} / \mathrm{kg}$ for Oliwin; and $54.2 \pm 1.3,170.4 \pm 3.7$, and $421.7 \pm 6.0 \mathrm{~g} / \mathrm{kg}$ for Jantarol, respectively. The contents of soluble and insoluble dietary fibre (determined according to the Association of Official Analytical Chemists method-AOAC 991.43 [32]) were $209.4 \pm 10.5$ and $71.3 \pm 10.5 \mathrm{~g} / \mathrm{kg}$ for Szafir, $212.8 \pm 11.3$ and $74.7 \pm 4.6 \mathrm{~g} / \mathrm{kg}$ for Oliwin, and $221.0 \pm 1.8$ and $93.6 \pm 11.6 \mathrm{~g} / \mathrm{kg}$ for Jantarol, respectively. 
The seeds were roasted in the oven (convection oven, CCC series, Rational, Landsberg am Lech, Germany) for $8 \mathrm{~min}$ at temperatures of 160,180 , and $200^{\circ} \mathrm{C}$. The thermal treatment of the flaxseeds was conducted according to the procedure described in detail by Waszkowiak et al. [28]. The parameters were selected on the basis of the previous results $[25,29,30,33]$ in order to maintain the acceptable sensory quality of roasted flax seeds. The seeds were roasted in a thin layer $(3 \mathrm{~mm})$ to achieve homogenous thermal stress.

Defatted flaxseed meals from the raw and roasted test samples were used for analyses of the electrophoretic protein profile, antiradical capacity and MRP formation. The raw and roasted flaxseed samples were ground in a ZM 200 mill (1 mm sieve, Retsch, Haan, Germany). Double cold oil extraction with n-hexane (ground flaxseed to solvent ratio of 1:3 w/v) was performed [34,35]. Then the meals were ground in a colloidal mill (Foss, Hilleroed, Denmark) to standardize the composition of the tested material. The meals were cold-stored at $4{ }^{\circ} \mathrm{C}$.

\subsection{Standards and Reagents}

Trichloroacetic acid (TCA), 6-hydroxy-2,5,7,8-tetramethylchromane-2-carboxylic acid (Trolox) and 2,2'-azobis (2-amidinopropane) dihydrochloride (AAPH) were purchased from Sigma-Aldrich (Munich, Germany). Bromophenol blue sodium salt $\left(3^{\prime}, 3^{\prime \prime}, 5^{\prime}, 5^{\prime \prime}\right.$-tetrabromophenol sulfophthalein sodium salt), 2-mercaptoethanol, acrylamide, $\mathrm{N}, \mathrm{N}^{\prime}$-methylenebisacrylamide, sodium dodecylsulphate (SDS), and Coomassie Brilliant Blue R-250 were purchased from SERVA Electrophoresis GmbH (Munich, Germany). PageRuler Plus Protein Ladder 10 to $250 \mathrm{kDa}$ was purchased from Thermo Fisher Scientific (Waltham, MA, USA), and 2-D Quant Kit from GE Healthcare Bio-Sciences (Marlborough, MA, USA). Fluorescein sodium salt was purchased from Fluka (Everett, WA, USA). Pronase E (4,000,000 PU/g) was purchased from Merck (Darmstadt, Germany). Other solvents and reagents of analytical (ACS) or HPLC grade were purchased from Sigma-Aldrich, SERVA Electrophoresis (Munich, Germany) or POCH (Gliwice, Poland).

\subsection{Chemical Composition Analysis}

The chemical composition of the untreated (raw) and roasted flaxseed samples was determined according to ISO standards. The moisture content [36], protein content (the Kjeldahl method, with a Kjeltec 2200 distillation unit, Foss, Hilleroed, Denmark; [37] and fat content (the extraction-weight method with the Soxtec HT6 system, Foss; [38] were all analyzed (see Supplementary Materials Table S1).

\subsection{Electrophoretic Protein Separation (SDS-PAGE)}

The electrophoretic analysis (SDS-PAGE) of defatted meals from untreated and roasted flaxseeds was performed under reducing (R) and non-reducing (NR) conditions (i.e., with or without DTT and 2-mercaptoethanol in a sample buffer and reservoir buffer for electrophoresis, respectively) according to the procedure described by Waszkowiak et al. [29]. The separation was performed in $15 \%$ polyacrylamide separating gel. The protein content in each separated sample was $12 \mu \mathrm{g}$ (it was measured with a 2-D Quant Kit, GE Healthcare Bio-Sciences, Marlborough, MA, USA). Gel images were acquired with an ImageMaster VDS imaging system and analyzed with the ImageMaster 1D Elite v.4.0 programme (Pharmacia Biotech, Vienna, Austria). Semi-quantitative analysis of selected peaks with a PageRuler Plus Protein Ladder 10 to $250 \mathrm{kDa}$ (Thermo Scientific, Waltham, MA, USA) was based on the molecular weight (MW) expressed as kiloDaltons (kDa). Computations were based on the assumption that the area of a single protein band amounted to the percentage ratio of the area of all separated protein bands (Figure 1), which was $100 \%$. The percentage share of protein bands was analyzed statistically. 
(a)

(b)
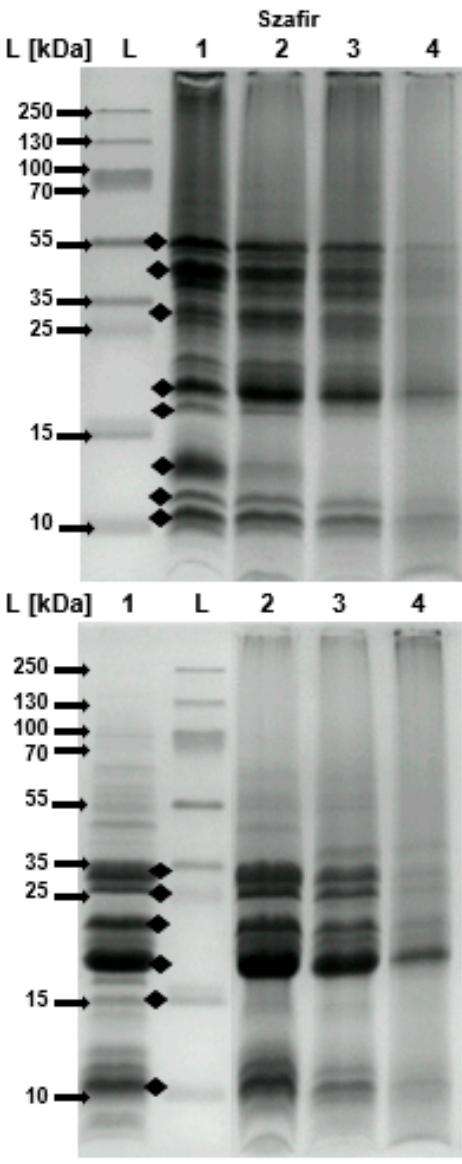
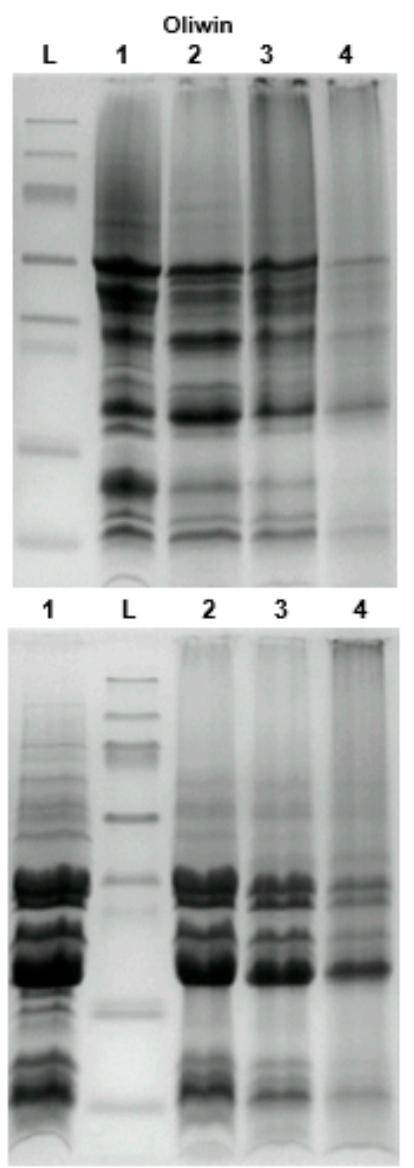
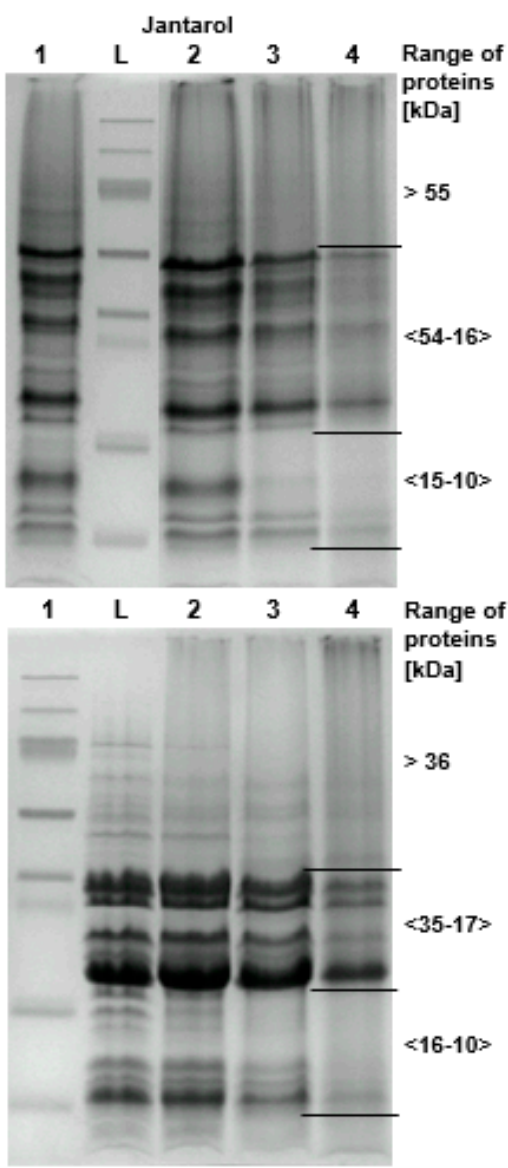

Figure 1. Analysis of untreated and thermal pretreated flaxseed samples by SDS-PAGE electrophoresis in non-reducing (a) and reducing (b) conditions. Line L-protein ladder (nine proteins spanning: 10, $15,25,35,55,70,100,130$, and $250 \mathrm{kDa}$ ); 1 - untreated; 2 -roasted $160{ }^{\circ} \mathrm{C}, 8 \mathrm{~min}$; 3 -roasted $180{ }^{\circ} \mathrm{C}$, $8 \mathrm{~min}$; 4 -roasted $200{ }^{\circ} \mathrm{C}, 8 \mathrm{~min}$. Black dots indicate major bands of the protein profile.

\subsection{Maillard Reaction Product Analysis (Browning Index)}

The Maillard reaction product (MRP) was measured with the method described by Palombo et al. [39] with some modifications [40]. Bound-to-protein and free forms of the MRP were determined.

For determine of the total MRP (both bound-to-protein and free forms), digestion $\left(40^{\circ} \mathrm{C}\right.$ for $48 \mathrm{~h}$ ) of a sample with Pronase E was applied to release MRP compounds from protein binding, followed by deproteinisation with TCA (the final concentration of $7 \%$ ) and centrifugation at $15,000 \times g$ for $15 \mathrm{~min}$ at $4{ }^{\circ} \mathrm{C}$. For analysis of free MRP (F-MRP), a sample was only deproteinised with TCA and centrifuged. The detailed procedure was described by Waszkowiak et al. [28].

In the case of both free and total MRP, the absorbance of supernatants was measured (AU420) at a wavelength of $420 \mathrm{~nm}$ (Specord 40 spectrophotometer, Analytik Jena, Jena, Germany). The absorbance at $550 \mathrm{~nm}$ (AU550) was also measured to allow for any turbidity in the sample [40]. The browning indexes (BI) for free and total MRP were based on the following equation: $\mathrm{BI}\left(\mathrm{AU}_{420^{*}}\right)=\mathrm{AU} 420-\mathrm{AU} 550$ and expressed as corrected arbitral absorbance unit $\left(\mathrm{AU}_{420^{*}}\right)$ per $\mathrm{g}$ of sample. The bound MPR (B-MRP) was calculated by subtracting the BI of free MRP from the BI of total MPR.

\subsection{Antiradical Capacity—ORAC_FL Assay}

The oxygen radical absorbance capacity assay with fluorescein as a fluorescent probe (ORAC_FL) assay by Ou et al. [41], which measures scavenging activity against peroxyl radical induced by AAPH, were carried out following the previously described procedure [42]. The assay was conducted in 
$75 \mathrm{mM}$ phosphate buffer ( $\mathrm{pH} 7.4)$ at $37^{\circ} \mathrm{C}$. The fluorescence of fluorescein was recorded at fluorescence spectrophotometer (Hitachi F-2700, Tokyo, Japan; $493 \mathrm{~nm}$ excitation and $515 \mathrm{~nm}$ emission wavelength) before and every $5 \mathrm{~min}$ after APPH addition for $40 \mathrm{~min}$.

Samples $(0.025 \mathrm{~g}$ of the defatted meals) were extracted $1 \mathrm{~h}$ with $25 \mathrm{~mL}$ of deionised water at room temperature by periodical mixing in a vortex. Next, they were centrifuged at $15,000 \times g$ for $15 \mathrm{~min}$ at $4{ }^{\circ} \mathrm{C}$ (Heraeus Megafuge 40R centrifuge, Thermo Fisher Scientific, Santa Clara, CA, USA). Supernatants were collected and filtered through Whatman ${ }^{\circledR}$ Grade 1 filter paper. Then the supernatants were diluted to concentrations within the assay activity ranges (the final concentrations were: $0.25 \mathrm{~g} / \mathrm{L}$ - untreated seeds and $0.50 \mathrm{~g} / \mathrm{L}$-roasted seeds). Trolox solutions $(0-100 \mu \mathrm{mol} / \mathrm{L})$ were used as standards. The results were calculated by subtracting the areas under the fluorescein decay curves for the control sample and the test sample (net area) and were expressed as $\mu \mathrm{mol}$ of Trolox equivalents (TE) per gram of defatted meal. Three independent analyses were performed for each sample.

\subsection{Statistical Analyses}

The roasting was conducted three times, with an individual experiment for each cultivar. All analyses were performed in triplicate. The results were shown as means \pm standard deviation (SD).

The results were analyzed statistically with the Statistica v.13.1 software (StatSoft, Tulsa, OK, USA). The effects of the flaxseed treatment $\left(\mathrm{L}=4\right.$ : untreated and roasted for $8 \mathrm{~min}$. at $\left.160{ }^{\circ} \mathrm{C}, 180^{\circ} \mathrm{C}, 200^{\circ} \mathrm{C}\right)$ and cultivar ( $\mathrm{L}=3$ : Oliwin, Jantarol, and Szafir) were analyzed. Analysis of variance (ANOVA) for a completely randomised design (CRD) was carried out. Then, post hoc Tukey's test was applied at a significance level $p<0.05$ to compare the means and show the effect of the pre-treatment.

Relationships between the variables were examined with linear regression analyses, and Pearson's correlation coefficients $(r)$ were calculated. Principal component analysis (PCA) was applied to the datasets from the treatment conditions and various flaxseed cultivars using the mean values of six variables, i.e., F-MRP; B-MRP; ORAC_FL; and 17-kDa, 13-kDa and 19-kDa shear in SDS-PAGE protein profiles.

\section{Results and Discussion}

\subsection{Effect of Flaxseed Roasting on Protein Profile}

The chemical composition of the untreated (raw) and roasted flaxseed samples are shown in the Supplementary Materials (Table S1).

The electrophoretic protein separations (SDS-PAGE NR and SDS-PAGE R) of defatted flaxseed meals and the percentage share of the main protein fractions in the protein profiles are reported in Figure 1 and Tables 1 and 2, respectively.

Table 1. The effect of flaxseed roasting on changes in the protein profile of defatted meals-the SDS-PAGE under non-reducing conditions.

\begin{tabular}{|c|c|c|c|c|c|c|}
\hline \multirow[b]{2}{*}{ Band } & \multirow[b]{2}{*}{ Protein $\approx$ MW $(\mathbf{k D a})$} & \multirow[b]{2}{*}{ Flaxseed Cultivar } & \multicolumn{4}{|c|}{ Thermal Treatment } \\
\hline & & & Untreated & \multicolumn{3}{|c|}{ Roasted } \\
\hline \multicolumn{7}{|c|}{ Protein contribution (\%) } \\
\hline \multirow{4}{*}{$1 \mathrm{a}$} & \multirow{3}{*}{53} & Szafir & $10.10^{a} \pm 0.25$ & $9.65^{b} \pm 0.13$ & $8.16^{d} \pm 0.12$ & $8.68^{c} \pm 0.12$ \\
\hline & & Oliwin & $14.82^{\mathrm{a}} \pm 0.28$ & $13.37^{b} \pm 0.06$ & $14.25^{\mathrm{a}} \pm 0.38$ & $10.46^{c} \pm 0.25$ \\
\hline & & Jantarol & $13.62^{c} \pm 0.03$ & $13.71^{c} \pm 0.04$ & $15.80^{\mathrm{a}} \pm 0.14$ & $14.39^{b} \pm 0.13$ \\
\hline & \multirow{3}{*}{45} & Szafir & $13.48^{\mathrm{a}} \pm 0.14$ & $12.40^{\mathrm{b}} \pm 0.05$ & $10.32^{c} \pm 0.28$ & $7.57^{\mathrm{d}} \pm 0.11$ \\
\hline \multirow[t]{3}{*}{$2 a$} & & Oliwin & $9.28^{a} \pm 0.27$ & $4.34^{b} \pm 0.04$ & $9.10^{\mathrm{a}} \pm 0.13$ & $4.40^{b} \pm 0.41$ \\
\hline & & Jantarol & $11.80^{\mathrm{a}} \pm 0.55$ & $11.64^{\mathrm{a}} \pm 0.52$ & $11.20^{\mathrm{a}} \pm 0.59$ & $3.29^{b} \pm 0.37$ \\
\hline & \multirow{3}{*}{31} & Szafir & $8.65^{d} \pm 0.22$ & $19.29^{a} \pm 0.10$ & $18.12^{\mathrm{b}} \pm 0.54$ & $17.23^{c} \pm 0.05$ \\
\hline \multirow[t]{3}{*}{$3 a$} & & Oliwin & $9.62^{c} \pm 0.21$ & $18.81^{\mathrm{a}} \pm 0.04$ & $11.85^{b} \pm 0.04$ & $18.96^{\mathrm{a}} \pm 0.31$ \\
\hline & & Jantarol & $13.48^{\mathrm{d}} \pm 0.22$ & $15.67^{c} \pm 0.10$ & $17.56^{\mathrm{b}} \pm 0.40$ & $23.29^{a} \pm 0.50$ \\
\hline & \multirow{3}{*}{19} & Szafir & $15.03^{\mathrm{d}} \pm 0.25$ & $24.94^{c} \pm 0.34$ & $29.53^{b} \pm 1.34$ & $41.02^{\mathrm{a}} \pm 0.36$ \\
\hline \multirow[t]{2}{*}{$4 a$} & & Oliwin & $12.82^{\mathrm{d}} \pm 0.33$ & $25.21^{c} \pm 0.22$ & $26.70^{\mathrm{b}} \pm 0.11$ & $46.84^{\mathrm{a}} \pm 0.31$ \\
\hline & & Jantarol & $17.31^{\mathrm{d}} \pm 0.09$ & $18.96^{\mathrm{c}} \pm 0.07$ & $27.18^{b} \pm 0.43$ & $42.31^{\mathrm{a}} \pm 0.54$ \\
\hline
\end{tabular}


Table 1. Cont.

\begin{tabular}{|c|c|c|c|c|c|c|}
\hline \multirow[b]{2}{*}{ Band } & \multirow[b]{2}{*}{ Protein $\approx$ MW (kDa) } & \multirow[b]{2}{*}{ Flaxseed Cultivar } & \multicolumn{4}{|c|}{ Thermal Treatment } \\
\hline & & & Untreated & $160^{\circ} \mathrm{C}$ & $\begin{array}{c}\text { Roasted } \\
180^{\circ} \mathrm{C}\end{array}$ & $200^{\circ} \mathrm{C}$ \\
\hline \multirow{3}{*}{$5 a$} & & Szafir & $3.58^{a} \pm 0.09$ & $2.13^{b} \pm 0.04$ & $1.40^{\mathrm{c}} \pm 0.43$ & $0.00^{\mathrm{d}} \pm 0.00$ \\
\hline & 17 & Oliwin & $4.04^{\mathrm{a}} \pm 0.18$ & $2.41^{b} \pm 0.02$ & $4.13^{\mathrm{a}} \pm 0.20$ & $0.00^{c} \pm 0.00$ \\
\hline & & Jantarol & $4.67^{\mathrm{a}} \pm 0.00$ & $3.21^{c} \pm 0.02$ & $4.12^{b} \pm 0.24$ & $0.00^{\mathrm{d}} \pm 0.00$ \\
\hline \multirow{4}{*}{$6 a$} & & Szafir & $25.88^{\mathrm{a}} \pm 0.52$ & $4.61^{b} \pm 0.16$ & $0.20^{c} \pm 0.01$ & $0.00^{c} \pm 0.00$ \\
\hline & 13 & Oliwin & $28.54^{\mathrm{a}} \pm 0.06$ & $10.33^{b} \pm 0.24$ & $3.74^{c} \pm 0.13$ & $0.00^{\mathrm{d}} \pm 0.00$ \\
\hline & & Jantarol & $19.06^{\mathrm{a}} \pm 0.09$ & $16.92^{b} \pm 0.35$ & $2.71^{c} \pm 0.09$ & $0.00^{\mathrm{d}} \pm 0.00$ \\
\hline & & Szafir & $4.50^{c} \pm 0.06$ & $5.04^{\mathrm{b}} \pm 0.11$ & $6.02^{\mathrm{a}} \pm 0.26$ & $3.86^{\mathrm{d}} \pm 0.13$ \\
\hline \multirow[t]{2}{*}{$7 \mathrm{a}$} & 12 & Oliwin & $3.42^{b} \pm 0.15$ & $3.99^{b} \pm 0.03$ & $5.62^{\mathrm{a}} \pm 0.02$ & $3.55^{b} \pm 0.41$ \\
\hline & & Jantarol & $3.48^{\mathrm{d}} \pm 0.02$ & $4.34^{\mathrm{b}} \pm 0.03$ & $4.73^{\mathrm{a}} \pm 0.03$ & $4.06^{c} \pm 0.04$ \\
\hline \multirow{3}{*}{$8 \mathrm{a}$} & & Szafir & $8.85^{c} \pm 0.24$ & $13.21^{\mathrm{ab}} \pm 0.39$ & $12.39^{b} \pm 0.52$ & $13.57^{\mathrm{a}} \pm 0.18$ \\
\hline & 11 & Oliwin & $7.04^{a} \pm 0.13$ & $10.38^{b} \pm 0.01$ & $12.71^{\mathrm{a}} \pm 0.11$ & $10.41^{\mathrm{b}} \pm 0.31$ \\
\hline & & Jantarol & $5.32^{\mathrm{d}} \pm 0.09$ & $6.17^{c} \pm 0.04$ & $7.31^{b} \pm 0.17$ & $8.00^{a} \pm 0.09$ \\
\hline \multicolumn{7}{|c|}{ Proteins at MW range } \\
\hline \multirow{4}{*}{ Ia } & & Szafir & $1.54^{\mathrm{a}} \pm 0.02$ & $1.29^{b} \pm 0.01$ & $0.00^{c} \pm 0.00$ & $0.00^{c} \pm 0.00$ \\
\hline & $>55$ & Oliwin & $2.44^{\mathrm{a}} \pm 0.05$ & $2.19^{b} \pm 0.13$ & $0.00^{c} \pm 0.00$ & $0.00^{c} \pm 0.00$ \\
\hline & & Jantarol & $2.07^{\mathrm{a}} \pm 0.01$ & $1.32^{b} \pm 0.13$ & $0.00^{c} \pm 0.00$ & $0.00^{c} \pm 0.00$ \\
\hline & & Szafir & $59.03^{\mathrm{d}} \pm 0.00$ & $75.86^{c} \pm 0.33$ & $81.41^{b} \pm 0.78$ & $82.58^{a} \pm 0.06$ \\
\hline \multirow[t]{3}{*}{ IIa } & $54-16$ & Oliwin & $58.57^{\mathrm{d}} \pm 0.10$ & $73.13^{c} \pm 0.34$ & $77.93^{b} \pm 0.22$ & $86.06^{a} \pm 0.10$ \\
\hline & & Jantarol & $70.07^{\mathrm{d}} \pm 0.01$ & $71.27^{c} \pm 0.40$ & $85.26^{b} \pm 0.11$ & $87.94^{\mathrm{a}} \pm 0.14$ \\
\hline & & Szafir & $39.45^{\mathrm{a}} \pm 0.00$ & $22.86^{\mathrm{b}} \pm 0.34$ & $18.61^{\mathrm{c}} \pm 0.79$ & $17.42^{\mathrm{d}} \pm 0.06$ \\
\hline \multirow[t]{2}{*}{ IIIa } & $15-10$ & Oliwin & $39.00^{a} \pm 0.08$ & $24.69^{b} \pm 0.21$ & $22.07^{c} \pm 0.22$ & $13.96^{\mathrm{d}} \pm 0.10$ \\
\hline & & Jantarol & $27.86^{\mathrm{a}} \pm 0.02$ & $27.42^{b} \pm 0.29$ & $14.74^{\mathrm{c}} \pm 0.11$ & $12.06^{\mathrm{d}} \pm 0.14$ \\
\hline
\end{tabular}

Protein contribution (\%)—-the percentage share of protein in the total protein content. MW—protein molecular weight. The means \pm SD marked with different superscript letters in a row are significantly different (one-way ANOVA, $p<0.05$, and post hoc Tukey's test).

Table 2. The effect of flaxseed roasting on changes in the protein profile of defatted meals-the SDS-PAGE under reducing conditions.

\begin{tabular}{|c|c|c|c|c|c|c|}
\hline \multirow[b]{2}{*}{ Band } & \multirow[b]{2}{*}{ Protein $\approx$ MW $(\mathbf{k D a})$} & \multirow[b]{2}{*}{ Flaxseed Cultivar } & \multicolumn{4}{|c|}{ Thermal Treatment } \\
\hline & & & Untreated & $160^{\circ} \mathrm{C}$ & Roasted & $200^{\circ} \mathrm{C}$ \\
\hline \multicolumn{7}{|c|}{ Protein contribution $(\%)$} \\
\hline \multirow{4}{*}{$1 \mathrm{~b}$} & & Szafir & $21.59^{a} \pm 0.52$ & $17.90^{\mathrm{b}} \pm 0.80$ & $15.71^{c} \pm 0.67$ & $6.88^{\mathrm{d}} \pm 0.27$ \\
\hline & 32 & Oliwin & $30.82^{\mathrm{a}} \pm 1.17$ & $27.13^{b} \pm 0.63$ & $24.47^{c} \pm 0.13$ & $20.08^{\mathrm{d}} \pm 0.77$ \\
\hline & & Jantarol & $26.31^{\mathrm{a}} \pm 1.24$ & $26.65^{a} \pm 0.12$ & $25.61^{\mathrm{a}} \pm 0.04$ & $20.96^{b} \pm 0.01$ \\
\hline & & Szafir & $9.15^{b} \pm 0.54$ & $8.86^{\mathrm{b}} \pm 0.24$ & $10.71^{\mathrm{a}} \pm 0.29$ & $4.99^{c} \pm 0.14$ \\
\hline \multirow[t]{3}{*}{$2 b$} & 27 & Oliwin & $10.15^{c} \pm 1.43$ & $11.59^{\mathrm{b}, \mathrm{c}} \pm 0.48$ & $13.09^{\mathrm{a}, \mathrm{b}} \pm 0.24$ & $14.19^{\mathrm{a}} \pm 0.93$ \\
\hline & & Jantarol & $11.61^{\mathrm{d}} \pm 1.30$ & $13.15^{\mathrm{b}} \pm 0.01$ & $15.01^{\mathrm{a}} \pm 0.07$ & $15.73^{\mathrm{a}} \pm 0.10$ \\
\hline & & Szafir & $9.99^{a} \pm 0.11$ & $5.60^{c} \pm 0.12$ & $6.90^{b} \pm 0.11$ & $0.00^{\mathrm{d}} \pm 0.00$ \\
\hline \multirow[t]{3}{*}{$3 b$} & 20 & Oliwin & $8.39^{a} \pm 0.02$ & $7.12^{b} \pm 0.15$ & $6.78^{c} \pm 0.01$ & $4.71^{\mathrm{d}} \pm 0.05$ \\
\hline & & Jantarol & $7.57^{b} \pm 0.04$ & $8.20^{a} \pm 0.05$ & $7.42^{\mathrm{c}} \pm 0.04$ & $0.00^{\mathrm{d}} \pm 0.00$ \\
\hline & & Szafir & $20.04^{c} \pm 0.02$ & $20.80^{c} \pm 0.53$ & $41.33^{b} \pm 0.58$ & $63.76^{\mathrm{a}} \pm 0.04$ \\
\hline \multirow[t]{3}{*}{$4 \mathrm{~b}$} & 17 & Oliwin & $22.14^{\mathrm{d}} \pm 0.04$ & $28.70^{c} \pm 0.08$ & $37.85^{\mathrm{b}} \pm 0.00$ & $52.24^{\mathrm{a}} \pm 0.02$ \\
\hline & & Jantarol & $23.07^{\mathrm{d}} \pm 0.13$ & $27.68^{c} \pm 0.10$ & $33.60^{\mathrm{b}} \pm 0.32$ & $49.48^{\mathrm{a}} \pm 0.25$ \\
\hline & & Szafir & $2.76^{\mathrm{a}} \pm 0.00$ & $1.81^{\mathrm{b}} \pm 0.04$ & $1.37^{\mathrm{c}} \pm 0.01$ & $0.00^{\mathrm{d}} \pm 0.00$ \\
\hline \multirow[t]{3}{*}{$5 b$} & 15 & Oliwin & $2.69^{a} \pm 0.06$ & $0.00^{b} \pm 0.00$ & $0.00^{b} \pm 0.00$ & $0.00^{\mathrm{b}} \pm 0.00$ \\
\hline & & Jantarol & $3.37^{\mathrm{a}} \pm 0.07$ & $1.02^{b} \pm 0.00$ & $0.00^{\mathrm{c}} \pm 0.00$ & $0.00^{\mathrm{c}} \pm 0.00$ \\
\hline & & Szafir & $20.60^{b} \pm 0.35$ & $24.96^{\mathrm{a}} \pm 0.06$ & $10.61^{\mathrm{d}} \pm 0.38$ & $11.8^{c} \pm 0.08$ \\
\hline \multirow[t]{2}{*}{$6 b$} & 11 & Oliwin & $10.38^{b} \pm 0.07$ & $13.96^{\mathrm{a}} \pm 0.41$ & $8.54^{c} \pm 0.07$ & $5.58^{\mathrm{d}} \pm 0.06$ \\
\hline & & Jantarol & $11.56^{\mathrm{a}} \pm 0.02$ & $11.77^{\mathrm{a}} \pm 0.35$ & $8.78^{b} \pm 0.08$ & $4.45^{\mathrm{c}} \pm 0.04$ \\
\hline \multicolumn{7}{|c|}{ Proteins at MW range } \\
\hline \multirow{4}{*}{$\mathrm{Ib}$} & & Szafir & $4.99^{b} \pm 0.03$ & $3.29^{d} \pm 0.06$ & $6.49^{a} \pm 0.21$ & $4.61^{c} \pm 0.03$ \\
\hline & $>36$ & Oliwin & $6.84^{\mathrm{a}} \pm 0.06$ & $4.81^{\mathrm{c}} \pm 0.05$ & $5.91^{\mathrm{b}} \pm 0.14$ & $2.63^{\mathrm{d}} \pm 0.03$ \\
\hline & & Jantarol & $6.63^{a} \pm 0.01$ & $3.69^{c} \pm 0.01$ & $5.01^{b} \pm 0.06$ & $6.11^{a} \pm 0.06$ \\
\hline & & Szafir & $63.15^{c} \pm 0.12$ & $53.36^{\mathrm{d}} \pm 1.20$ & $75.23^{\mathrm{b}} \pm 0.08$ & $83.51^{\mathrm{a}} \pm 0.12$ \\
\hline \multirow[t]{3}{*}{$\mathrm{IIb}$} & $35-17$ & Oliwin & $71.68^{\mathrm{d}} \pm 0.38$ & $75.28^{c} \pm 0.07$ & $82.75^{\mathrm{b}} \pm 0.14$ & $91.79^{a} \pm 0.09$ \\
\hline & & Jantarol & $75.33^{d} \pm 0.04$ & $78.37^{c} \pm 0.21$ & $82.27^{b} \pm 0.31$ & $89.45^{\mathrm{a}} \pm 0.12$ \\
\hline & & Szafir & $29.39^{b} \pm 0.08$ & $39.33^{\mathrm{a}} \pm 0.22$ & $14.40^{\mathrm{c}} \pm 0.42$ & $11.81^{\mathrm{d}} \pm 0.08$ \\
\hline \multirow[t]{2}{*}{$\mathrm{IIIb}$} & $16-10$ & Oliwin & $21.01^{\mathrm{a}} \pm 0.30$ & $18.26^{b} \pm 0.03$ & $11.35^{\mathrm{c}} \pm 0.01$ & $5.58^{\mathrm{d}} \pm 0.06$ \\
\hline & & Jantarol & $16.96^{\mathrm{a}} \pm 0.05$ & $17.13^{\mathrm{a}} \pm 0.23$ & $12.73^{\mathrm{b}} \pm 0.25$ & $4.45^{\mathrm{c}} \pm 0.04$ \\
\hline
\end{tabular}

Explanations as in Table 1. 
The SDS-PAGE NR meal profiles of all the flaxseed cultivars consisted of 13 components. Eight main protein bands (with MW of $\approx 53-11 \mathrm{kDa}$ ) were marked (black dots in Figure 1a) and described as 1a-8a (Table 1). The SDS-PAGE R profiles (Figure 1b) showed six main protein bands with MW of $\approx 32-11 \mathrm{kDa}$, which were described as $1 \mathrm{~b}-6 \mathrm{~b}$ (Table 2). These results were similar to the findings of our previous studies $[29,30]$. The protein profile of the untreated flaxseeds also corresponds with the results of SDS-PAGE profiles described previously for flaxseed meal [17] and flaxseed cake [43].

For selected cultivars (Oliwin, Jantarol, and Szafir), the SDS-PAGE profiles of the untreated samples showed similar pictures with a slight exception. The SDS-PAGE NR profile of Jantarol was characterized by the lower intensity of the $13 \mathrm{kDa}$ protein band than the Oliwin and Szafir profiles. This protein fraction in the seeds of the Jantarol, Szafir, and Oliwin cultivars amounted to $19 \%, 25.9 \%$, and $28.5 \%$, respectively (Table 1 ).

The roasting changed the share of the main fractions in the protein profiles (Figure 1). The most significant changes in the SDS-PAGE NR profiles of the roasted flax seeds of each cultivar (Figure 1a and Table 1) were observed in the protein fractions at MWs of $\approx 13 \mathrm{kDa}(6 \mathrm{a})$ and $\approx 19 \mathrm{kDa}(4 \mathrm{a})$, and these changes were related to the roasting temperature $(\mathrm{r}=-0.914, p<0.0001$ and $\mathrm{r}=0.781, p=0.003$, respectively). The share of $13 \mathrm{kDa}$ proteins decreased considerably after roasting (Table 1 ). As the roasting temperature increased, the greatest changes in the percentage share of the $13 \mathrm{kDa}$ fraction were observed in the brown seed Szafir cultivar. The share of this fraction in the protein profiles of the untreated sample and those roasted at $160{ }^{\circ} \mathrm{C}$ and $180{ }^{\circ} \mathrm{C}$ amounted to $25.9 \%, 4.6 \%$ and $<1 \%$, respectively. The band disappeared from the protein profile of the Szafir seeds roasted at $200{ }^{\circ} \mathrm{C}$ (Figure 1a). As far as the golden-seed Oliwin and Jantarol cultivars are concerned, the share of the $13 \mathrm{kDa}$ protein fraction in the protein profiles of the untreated samples amounted to $28.5 \%$ and $19 \%$, in the samples roasted at $160{ }^{\circ} \mathrm{C}-10.3 \%$ and $16.9 \%$, and in those roasted at $180{ }^{\circ} \mathrm{C}-3.7 \%$ and $2.7 \%$, respectively. As for the Szafir seeds, the fraction disappeared from the protein profile of the Oliwin and Jantarol samples roasted at $200{ }^{\circ} \mathrm{C}$. On the other hand, the percentage of the $19 \mathrm{kDa}$ fraction in the protein profiles of the roasted seeds was significantly higher than in the untreated ones (Table 1 ). The share of this fraction amounted to $12.8-17.3 \%$ in the untreated samples, $18.9-25.2 \%$ in the samples roasted at $160{ }^{\circ} \mathrm{C}, 26.7-29.5 \%$ in those roasted at $180{ }^{\circ} \mathrm{C}$ and $41-46.8 \%$ in those roasted at $200{ }^{\circ} \mathrm{C}$. It is noteworthy that these changes seem to correspond with the changes in the $13 \mathrm{kDa}$ fraction.

As far as the SDS-PAGE R protein profiles are concerned (Figure 1b), in comparison with the untreated seeds the intensity of the protein bands in the seeds roasted at $180{ }^{\circ} \mathrm{C}$ and $200^{\circ} \mathrm{C}$ decreased significantly at $\mathrm{MW} \leq 15 \mathrm{kDa}$, irrespective of the flax cultivar. Moreover, there were significant changes in the protein profiles of roasted seeds of all cultivars at an MW of $\approx 17 \mathrm{kDa}$ (4b; Table 2), which were also related to the roasting temperature $(\mathrm{r}=0.694, p=0.012)$. The protein fraction in the untreated samples of the Szafir, Oliwin, and Jantarol seeds amounted to $20.4 \%, 22.1 \%$, and $23.1 \%$, respectively. The share of the $17 \mathrm{kDa}$ fraction in the protein profile of the samples roasted at $200{ }^{\circ} \mathrm{C}$ increased to $63.8 \%, 52.2 \%$, and $49.5 \%$, respectively. At MWs of $20 \mathrm{kDa}$ and $15 \mathrm{kDa}$, the protein fractions disappeared from the profiles of the samples roasted at $200{ }^{\circ} \mathrm{C}$ (except the Oliwin seeds at $20 \mathrm{kDa}$ ).

The changes in the SDS-PAGE protein profiles of roasted flaxseeds may have been caused by structural modifications of their proteins such as denaturation, aggregation, degradation, and cross-linking with polypeptides and other compounds [44]. Moreover, these changes may also have been induced by oxidation and Maillard reaction. The study by $\mathrm{Yu}$ [45] showed that the roasting of flaxseeds at $165^{\circ} \mathrm{C}$ significantly changed the secondary structure of proteins, inducing an increase in the $\beta$-sheet structure to the $\alpha$-helix structure ratio. It was attributed to the aggregation of proteins and the formation of an intramolecular $\beta$-sheet structure during the thermal treatment. $\mathrm{Yu}[45]$ also found that proteins and other compounds of the flaxseed matrix formed complexes because protein solubility decreased but the content of proteins bound to cell walls and bound to lignin, and/or Maillard reaction proteins increased. On the other hand, our previous research [28] on the effect of roasting (at temperatures of $160-220^{\circ} \mathrm{C}$ ) on flaxseed oil quality showed that oil oxidation stability deteriorated significantly. Oil oxidation in situ was particularly significantly accelerated by roasting at 
$\geq 200^{\circ} \mathrm{C}$. The acceleration of the oxidation process may also have influenced structural modifications of flaxseed proteins, which resulted in changes in the protein profiles of the flaxseeds roasted at $200{ }^{\circ} \mathrm{C}$.

It is noteworthy that the protein fraction in the roasted flaxseeds decreased at an MW of $13 \mathrm{kDa}$ but increased at MWs of $19 \mathrm{kDa}$ (SDS-PAGE NR) and $17 \mathrm{kDa}$ (SDS-PAGE R) in a treatment-dependent manner. These changes in proteins were also observed in our previous study after roasting flaxseeds for 8,16 , and $24 \mathrm{~min}$ at $160^{\circ} \mathrm{C}$ [30]. They may have been related to protein degradation, aggregation or formation of complexes with other seed compounds. Changes in the protein fraction of $13 \mathrm{kDa}$ may be characteristic of thermally treated flaxseeds because a similar decrease in this fraction was also observed in steamed flaxseeds [29,30]. The results of studies by Liu et al. [46] and Tehrani et al. [13] suggest that the $13 \mathrm{kDa}$ proteins, which are probably water-soluble albumin-like proteins, could be crucial for the functional and biological properties of flaxseeds. Liu et al. [46] showed that proteins at a similar MW were important for the emulsification ability of flaxseed extracts. Tehrani et al. [13] reported that they showed an antibacterial capacity. Further research is necessary to find whether roasting affects these properties.

\subsection{Effect of Flaxseed Roasting on the Formation of Free and Bound-To-Protein Maillard Reaction Product (MRP)}

The analysis of the MRP formation (based on BI values, Figure 2) showed that both free (F-MRP) and bound-to-protein (B-MRP) forms of Maillard reaction products were formed during the roasting of flaxseeds, regardless of the cultivar.

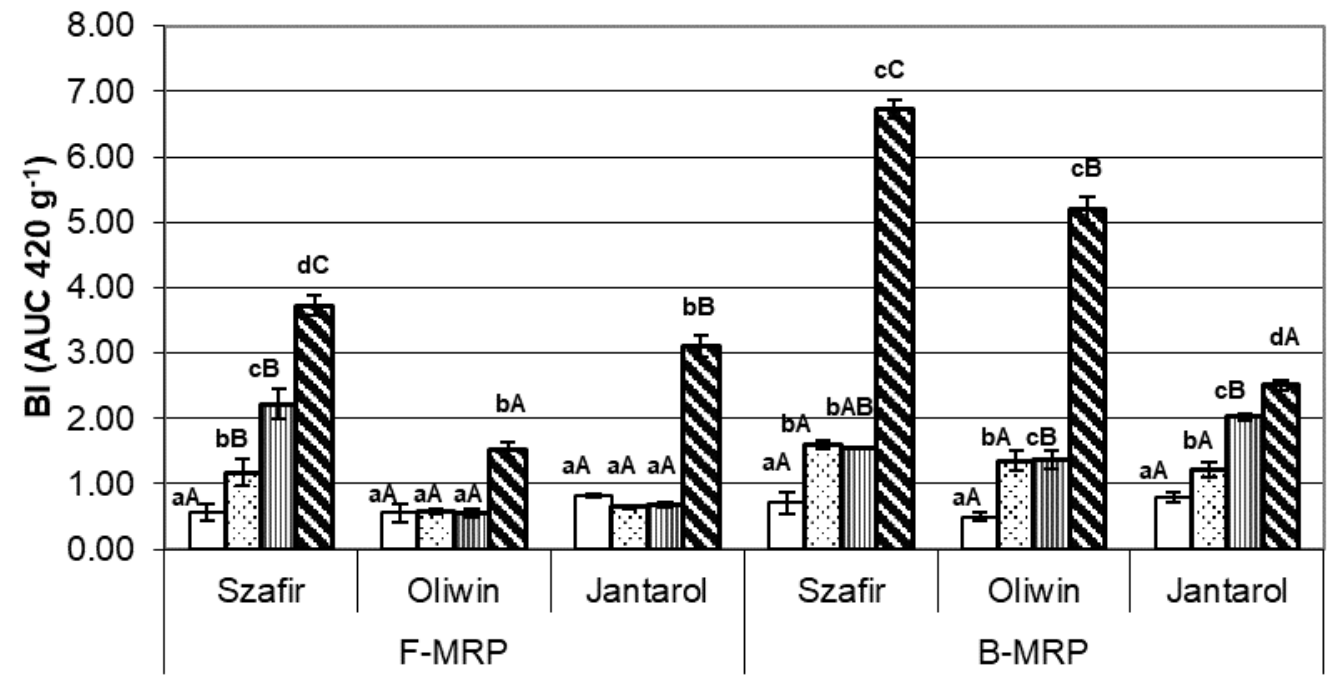

$$
\text { 口Untreated } \quad \text { R }-160^{\circ} \mathrm{C}, 8 \mathrm{~min} \quad \text { mR }-180^{\circ} \mathrm{C}, 8 \mathrm{~min} \quad \boldsymbol{R}-200^{\circ} \mathrm{C}, 8 \mathrm{~min}
$$

Figure 2. Free (F-MPR) and bound-to-protein (B-MPR) Maillard reaction products of the untreated and roasted flaxseeds, expressed as Browning Index (BI, AU420*/g flaxseed meal). Bars (means \pm $\mathrm{SD}$ ) marked with different letters are significantly different (one-way ANOVA, $p<0.05$, and post hoc Tukey's test): a, b, c, d-pre-treatment effect, A, B, C—cultivar effect.

The content of F-MRP increased gradually with the roasting temperature of the brown Szafir seeds. It was 6.5 times greater in the seeds roasted at $200{ }^{\circ} \mathrm{C}$ than in the untreated seeds. The F-MRP values of the golden seed Oliwin and Jantarol were significantly greater only after roasting at $200^{\circ} \mathrm{C}$.

The B-MRP content in the seeds of all tested cultivars roasted at $160^{\circ} \mathrm{C}$ and $180^{\circ} \mathrm{C}$ was about 1.5-2.7 times greater (statistically significant difference) than in the untreated seeds. Similar to F-MRP, the most dynamic increase in B-MRP was found after the roasting of flaxseeds at $200{ }^{\circ} \mathrm{C}$. The B-MRP 
content in the Szafir and Oliwin seeds was significantly greater than in the Jantarol seeds (the values were about 10 and three times greater than in the untreated seeds, respectively).

There was a significant relationship between the roasting temperature and B-MRP content $(\mathrm{r}=0.584, p=0.046)$, but the relationship between the roasting temperature and F-MRP $(r=0.497$, $p=0.100)$ was statistically insignificant.

The results showed that during the roasting of flaxseeds Maillard reaction products may be formed. It is possible that melanoidins were formed, i.e., brown nitrogen-containing Maillard reaction products. When Maillard reactions take place at a relatively high temperature (above $150^{\circ} \mathrm{C}$ ), in a short time and at low moisture during seed roasting [47], (like in our study), oligo- or polysaccharides in a matrix can react as complete molecules at reducing end and additional side chains could be formed by transglycosylation. As a result, high MW melanoidins with a carbohydrate skeleton may be formed. Alternatively, high MW melanoidins with a protein skeleton may be produced by the reaction of sugar or carbohydrate degradation products with proteins. Low MW melanoidins may also be formed under these conditions when sugar or carbohydrate degradation products react with amino acids and then they may be used to produce high MW melanoidins [47]. Low content of free reducing sugars [48] may limit MRP formation in roasted flaxseeds. The study by Epaminondas et al. (2011) showed that the degradation of triglycerides and cell wall carbohydrates may occur during the heating of flaxseeds above $170{ }^{\circ} \mathrm{C}$. Therefore, it could be assumed that the latter way of melanoidin formation is crucial for roasted flaxseeds and these degradation products interact with some flaxseed proteins and form high MW Maillard reaction products. Such products were probably identified in our study as B-MRP (Figure 2). This assumption is in agreement with our findings concerning the changes in the protein profile of the flaxseeds after roasting above $160^{\circ} \mathrm{C}$, especially at $200{ }^{\circ} \mathrm{C}$. The decrease in the band intensity (Figure 1) and percentage (Tables 1 and 2 ) of some proteins in both the SDS-PAGE NR and R profiles of the roasted flaxseeds, especially those at $\mathrm{MW} \leq 15 \mathrm{kDa}$, may indicate their contribution to the formation of high MW melanoidins. The contribution of thermally labile $13 \mathrm{kDa}$ protein may be important for the process. It may also explain the lower intensity of bound-to-protein MRP formation in the Jantarol seeds after roasting at $200^{\circ} \mathrm{C}$, as compared with the Szafir and Oliwin samples, because the raw Jantarol seeds were characterized by lower percentage of $13 \mathrm{kDa}$ in their protein profile. However, further research is necessary to confirm these suppositions.

During the roasting of flaxseeds at high temperatures, the formation of melanoidin molecules intensified. This phenomenon can be explained by the processes occurring at a temperature higher than $170^{\circ} \mathrm{C}$, which was described by Epaminondas et al. [49]. It seems that their intensification during roasting at high temperature may also favor MRP formation. Bekedam et al. [50] found that more intensive (darker) roasting of coffee also led to the formation of high MW melanoidins, which were detected in the coffee brew.

\subsection{Effect of Flaxseed Roasting on Antiradical Capacity (ORAC_FL)}

Table 3 shows the effect of flaxseed roasting within the range of selected temperatures on the antiradical capacity of defatted flaxseed meals, measured as scavenging activity against peroxyl radical (ORAC_FL assay).

The roasting process decreased the antiradical capacity of flaxseeds. The antiradical activity of the untreated seeds was significantly greater than that of the seeds roasted even at $160^{\circ} \mathrm{C}$, regardless of the flax cultivar. The lowest values were noted for the seeds roasted at $180^{\circ} \mathrm{C}$ and slightly higher for the seeds roasted at $200{ }^{\circ} \mathrm{C}$, but the increase was statistically significant only for the Szafir seeds. This observation is consistent with the results of our previous study [29], which showed that the thermal pre-treatment of flaxseeds (steaming and roasting at various times and temperatures conditions) negatively affected the antiradical activity of aqueous extracts prepared from these seeds. There was a negative linear correlation between the roasting time or temperature and the scavenging activity of aqueous extracts against peroxyl radical. In the present research, there was also a statistically 
significant negative linear correlation between the roasting temperature and the result of the ORAC_FL assay $(\mathrm{r}=-0.894, p<0.001)$.

Table 3. The antiradical capacity of the untreated and roasted flaxseeds_-ORAC_FL assay.

\begin{tabular}{|c|c|c|c|c|c|}
\hline \multirow{3}{*}{ Flaxseed Cultivar } & \multicolumn{4}{|c|}{ Thermal Treatment } & \multirow{3}{*}{$p$} \\
\hline & \multirow{2}{*}{ Untreated } & \multicolumn{3}{|c|}{ Roasted } & \\
\hline & & $160^{\circ} \mathrm{C}$ & $180^{\circ} \mathrm{C}$ & $200^{\circ} \mathrm{C}$ & \\
\hline Szafir & $136.05 \pm 0.87^{d, C}$ & $85.99 \pm 1.81^{c, B}$ & $57.94 \pm 2.98^{\mathrm{a}, \mathrm{A}}$ & $70.17 \pm 2.06^{b, B}$ & $<0.0001$ \\
\hline Oliwin & $100.82 \pm 1.73^{\mathrm{c}, \mathrm{A}}$ & $59.75 \pm 5.14 \mathrm{a}, \mathrm{A}$ & $56.92 \pm 2.15^{\mathrm{a}, \mathrm{A}}$ & $62.03 \pm 2.52^{a, A}$ & $<0.0001$ \\
\hline Jantarol & $130.70 \pm 4.23^{\mathrm{c}, \mathrm{B}}$ & $88.26 \pm 3.65^{b, B}$ & $69.74 \pm 7.30^{\mathrm{a}, \mathrm{B}}$ & $71.95 \pm 5.84^{\mathrm{a}, \mathrm{B}}$ & $<0.0001$ \\
\hline$p$ & $<0.0001$ & $<0.0001$ & 0.0069 & 0.0121 & \\
\hline
\end{tabular}

The results were expressed as Trolox equivalent $\mu \mathrm{M} / \mathrm{g}$ flaxseed meal. The means \pm SD marked with different superscript letters are significantly different (one-way ANOVA, $p<0.05$, and post hoc Tukey's test): a, b, c, d in a row-pre-treatment effect; A, B, C in a column-cultivar effect.

This finding supports our earlier assumption concerning the formation of MRP products such as melanoidins, which exhibit antiradical activity during roasting at $200^{\circ} \mathrm{C}$. There have been numerous studies $[47,51]$ reporting the antioxidative activity of high MW melanoidin fractions in various food products, both the chelating and radical-scavenging capacity. It was associated with the structural properties of melanoidin molecule as well as the presence of bound-to-melanoidin compounds such as phenolic compounds and low MW Maillard reaction products. The antioxidative capacity of these products may have improved slightly after roasting at $200{ }^{\circ} \mathrm{C}$, as shown in Table 3 . However, the antiradical capacity of these seeds was still significantly lower than that of the raw seeds. It showed that the formation of new antioxidative compounds during "dark" roasting was insufficient to overcome the degradation of some native antioxidants in the flaxseed matrix. Further research is necessary to investigate this problem.

\subsection{Relationship between Protein Profile, MRP, and Antiradical Capacity after Flaxseed Roasting}

The relations between the selected variables (the results of linear regression analysis) are shown in Table 4. Principal component analysis (PCA) was applied to show relations between these variables, i.e., the MRP content (both F-MRP and B-MRP), the antiradical capacity (ORAC_FL value) and the percentage of protein fraction at MWs of $13 \mathrm{kDa} N R, 19 \mathrm{kDa} \mathrm{NR}$, and $17 \mathrm{kDa} \mathrm{R}$ (the protein fractions whose share in the SDS-PAGE NR and R profiles was the most significantly influenced by roasting). PCA helped to derive the factors along which these variables can be classified and to map the tested variants (samples of various flaxseed cultivars roasted at various temperatures) into these factors.

Table 4. The relations between the selected variables, the roasting conditions and cultivar.

\begin{tabular}{|c|c|c|c|c|c|c|}
\hline \multirow{2}{*}{ Variabilities } & \multicolumn{6}{|c|}{ Correlation Coefficient $\mathbf{r}$} \\
\hline & 17 kDa R & 13 kDa NR & 19 kDa NR & ORAC_FL & MRP-F & MRP-B \\
\hline $13 \mathrm{kDa} N \mathrm{NR}$ & $-0.746^{* *}$ & - & - & - & - & - \\
\hline 19 kDa NR & $0.905^{* * *}$ & $-0.853^{* * *}$ & - & - & - & - \\
\hline ORAC_FL & $-0.618^{*}$ & $0.806^{* *}$ & $-0.657^{*}$ & - & - & - \\
\hline MRP-F & $0.829 * *$ & $-0.608^{*}$ & $0.745^{* *}$ & $-0.343 \mathrm{NS}$ & - & - \\
\hline MRP-B & $0.879^{* * *}$ & $-0.632 *$ & $0.837^{* *}$ & $-0.437 \mathrm{NS}$ & $0.731 * *$ & - \\
\hline Roasting & $0.694^{*}$ & $-0.914^{* * *}$ & $0.781 * *$ & $-0.894^{* * *}$ & $0.497 \mathrm{NS}$ & $0.584 *$ \\
\hline Cultivar & $-0.091 \mathrm{NS}$ & $0.080 \mathrm{NS}$ & $-0.046 \mathrm{NS}$ & $0.041 \mathrm{NS}$ & $-0.235 \mathrm{NS}$ & $-0.235 \mathrm{NS}$ \\
\hline
\end{tabular}

The analysis showed that the first two components (factor F1 and F2) were the most important elements explaining variation in the data. Because both factors explained approximately $90.3 \%$ of the total variance, they were selected for data interpretation (Figure 3) in our study. 
(a)

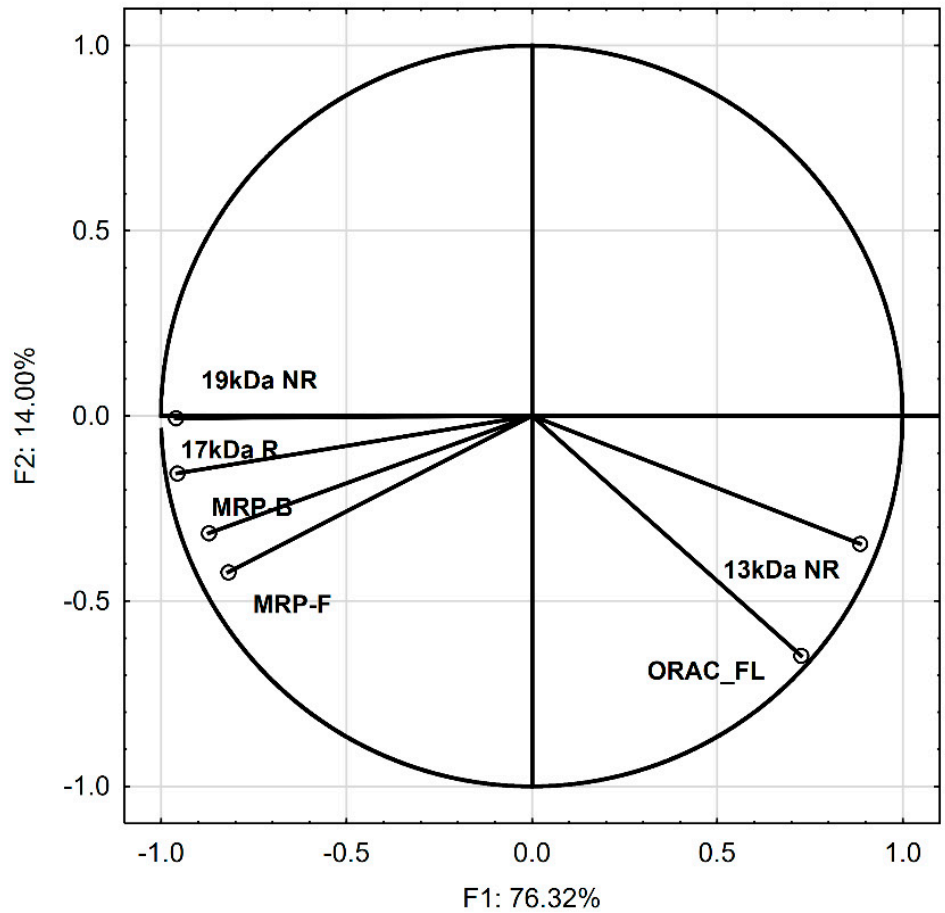

(b)

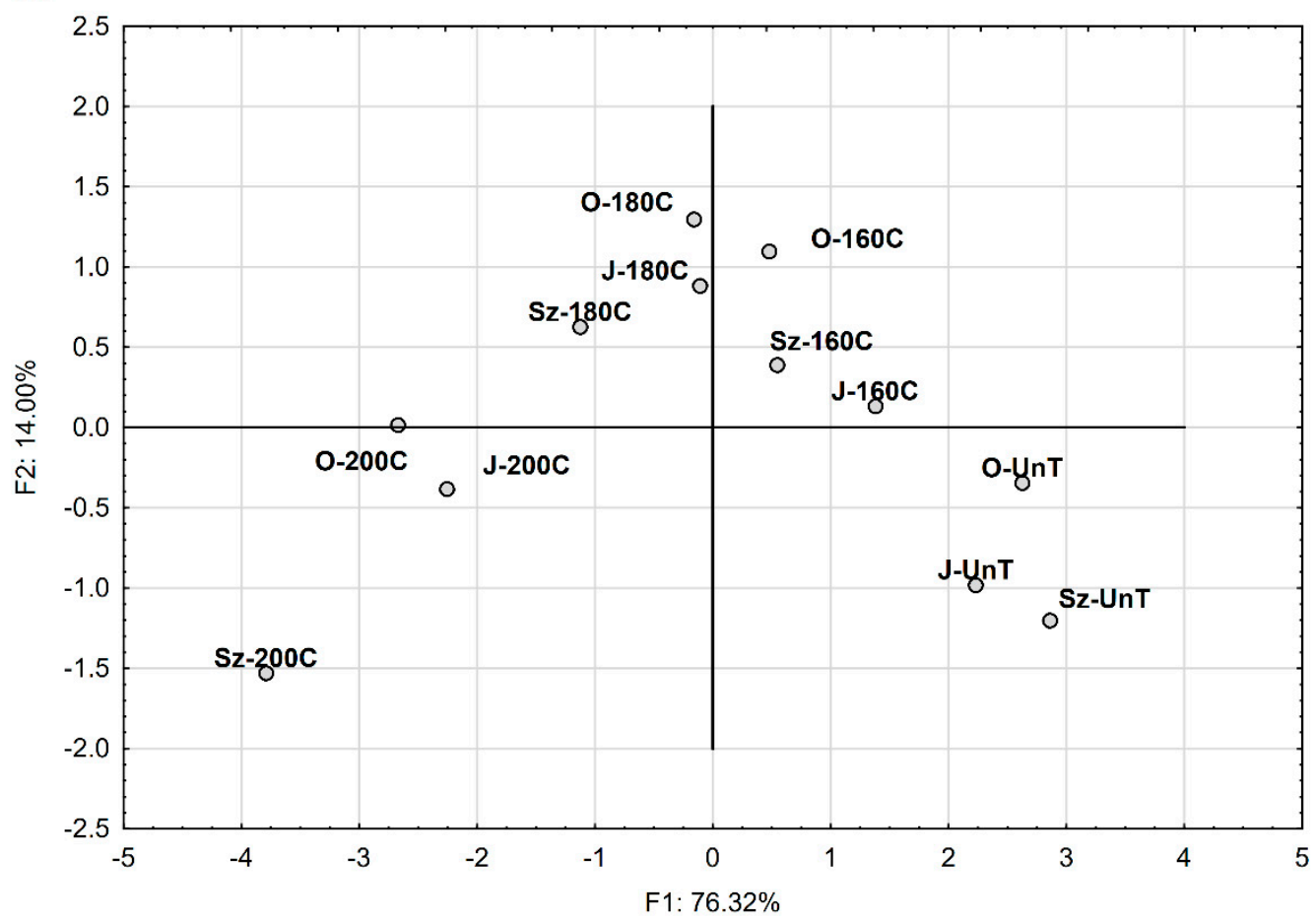

Figure 3. Plots of the first two principal components (F1 and F2): (a) variability-factor coordinates plot, (b) case-factor coordinates plot; flaxseed cultivars: Oliwin (O), Jantarol (J), and Szafir (Sz); flaxseed treatment: untreated (UnT) and roasted $\left(8 \mathrm{~min}\right.$. at $160^{\circ} \mathrm{C}, 180^{\circ} \mathrm{C}$ and $\left.200{ }^{\circ} \mathrm{C}\right)$.

The factor coordinates of the variables (Figure 3a) indicate that F1 was mostly explained by the changes in the protein share of $19 \mathrm{kDa} \mathrm{NR}, 17 \mathrm{kDa} \mathrm{R}(-0.96)$, and $13 \mathrm{kDa} \mathrm{NR}(0.88)$, and also by the F-MRP and B-MRP content ( -0.82 and -0.87 , respectively). On the other hand, factor F2 was mostly 
negatively correlated with the ORAC_FL values (the factor coordinate of this variable was -0.64 ), but the variable was also positively correlated with factor F1 (0.73).

Factor F1, which explained the total variance of selected variables $(76.32 \%)$ to the greatest extent, seems to show the significance of the roasting temperature: $<180{ }^{\circ} \mathrm{C}$ vs. $\geq 180{ }^{\circ} \mathrm{C}$ for the changes observed in the defatted flaxseed meals after roasting. The projection of the variants on the factor-plane $\mathrm{F} 1 \times \mathrm{F} 2$ (Figure $3 \mathrm{~b}$ ) shows that the flaxseeds roasted at $<180{ }^{\circ} \mathrm{C}$ had positive coordinate values for $\mathrm{F} 1$, whereas the ones roasted at $\geq 180^{\circ} \mathrm{C}$ had negative coordinate values. As far as factor F2 is concerned, this projection shows that the untreated flaxseeds and the ones roasted at $200{ }^{\circ} \mathrm{C}$ had negative coordinate values for the factor, whereas the flaxseeds roasted at $160{ }^{\circ} \mathrm{C}$ and $180{ }^{\circ} \mathrm{C}$ had positive coordinate values, regardless of the flax cultivar.

The regression analysis did not show a significant relation $(p \geq 0.05)$ between the cultivar and any of the selected variables (Table 4). The results suggest that, during flaxseed roasting, these changes occur regardless of the cultivar.

\section{Conclusions}

The most significant changes in the SDS-PAGE profiles of the roasted seeds of each cultivar were observed in the protein fractions at MWs of $13 \mathrm{kDa}$ (decrease) and $19 \mathrm{kDa}$ and $17 \mathrm{kDa}$ (increase). They may have been caused by structural modifications of flaxseed proteins upon thermal treatment as well as oxidation processes and MRP formation. Both F-MRP and B-MRP were formed during the roasting of flaxseeds, regardless of the cultivar. There was a significant relationship between the roasting temperature and B-MRP content. In comparison with the untreated seeds, the roasting process decreased the antiradical capacity of flaxseeds. The MRP formation slightly improved the antioxidative capacity after roasting at $200^{\circ} \mathrm{C}$, but it was still significantly lower than the antioxidative capacity of the raw seeds. It indicated that the MRP formation during "dark" roasting was insufficient to overcome the degradation of some native antioxidants of flaxseeds.

The research provides novel information about key protein fractions that seem to be important changing during heat treatment. However, further characterization of the $13 \mathrm{kDa}, 19 \mathrm{kDa}$ and $17 \mathrm{kDa}$ protein bands appears to be important. Our research only shows generally the protein fractions, not identifying specific proteins. In the future, the results of our work should be extended to the identification of specific proteins and peptides (using mass spectrometric analysis, e.g., LC-MS/MS) within the fractions that we have selected. It is also necessary to conduct further research on the contribution of these proteins to the MRP formation mechanism and their possible significance for the antioxidative system of flax seeds. Roasting may also influence the functional properties of flaxseed proteins because the functionality of plant proteins is often determined by their structure. The issues related to the influence of heat treatment on changes in protein profiles of flaxseed and the functionality of flaxseed proteins need to be continued.

Supplementary Materials: The following are available online at http://www.mdpi.com/2304-8158/9/10/1383/s1, Table S1: Composition $\left[\mathrm{g} \mathrm{kg}^{-1}\right]$ of untreated and thermally pre-treated flaxseeds.

Author Contributions: Conceptualization, K.W.; Formal analysis, K.W.; Investigation, K.W. and B.M.; Methodology, K.W. and B.M.; Validation, K.W.; Visualization, K.W. and B.M.; Writing-original draft, K.W. and B.M.; Writing-review and editing, K.W. and B.M. All authors have read and agreed to the published version of the manuscript.

Funding: This research was supported by statutory funds of the Department of Gastronomy Science and Functional Foods of the Poznan University of Life Sciences, grant number 506.751.03.00. The publication was co-financed within the framework of the Ministry of Science and Higher Education programme as "Regional Initiative Excellence" in years 2019-2022, project number 005/RID/2018/19.

Conflicts of Interest: The authors declare no conflict of interest. 


\section{References}

1. Goyal, A.; Sharma, V.; Upadhyay, N.; Gill, S.; Sihag, M. Flax and flaxseed oil: An ancient medicine and modern functional food. J. Food Sci. Technol. 2014, 51, 1633-1653. [CrossRef] [PubMed]

2. Rabetafika, H.N.; van Remoortel, V.; Danthine, S.; Paquot, M.; Blecker, C. Flaxseed proteins: Food uses and health benefits. Int. J. Food Sci. Technol. 2011, 46, 221-228. [CrossRef]

3. Bekhit, A.E.-D.A.; Shavandi, A.; Jodjaja, T.; Birch, J.; Teh, S.; Ahmed, I.A.M.; Al-Juhaimi, F.Y.; Saeedi, P.; Bekhit, A.A. Flaxseed: Composition, detoxification, utilization, and opportunities. Biocatal. Agric. Biotechnol. 2018, 13, 129-152. [CrossRef]

4. Marambe, H.K.; Wanasundara, J.P.D. Chapter 8-Protein from Flaxseed (Linum usitatissimum L.). In Sustainable Protein Sources; Nadathur, S.R., Wanasundara, J.P.D., Scanlin, L.B.T.-S.P.S., Eds.; Academic Press: San Diego, CA, USA, 2017; pp. 133-144. ISBN 978-0-12-802778-3.

5. Oomah, B.D.; Mazza, G. Flaxseed proteins-A review. Food Chem. 1993, 48, 109-114. [CrossRef]

6. Madhusudhan, K.T.; Singh, N. Isolation and characterization of a small molecular weight protein of linseed meal. Phytochemistry 1985, 24, 2507-2509. [CrossRef]

7. Marcone, M.F.; Kakuda, Y.; Yada, R.Y. Salt soluble seed globulins of various dicotyledonous and monocotyledonous plants I. Isolation/purification and characterization. Food Chem. 1998, 62, $27-47$. [CrossRef]

8. Youle, R.J.; Huang, A.H.C. Occurrence of low molecular weight and high cysteine conteining albumin storage proteins in oilseeds of diverse species. Am. J. Bot. 1981, 68, 44-48. [CrossRef]

9. Shim, Y.Y.; Gui, B.; Arnison, P.G.; Wang, Y.; Reaney, M.J.T. Flaxseed (Linum usitatissimum L.) bioactive compounds and peptide nomenclature: A review. Trends Food Sci. Technol. 2014, 38, 5-20. [CrossRef]

10. Alaswad, A.A.; Krishnan, H.B. Immunological investigation for the presence of lunasin, a chemopreventive soybean peptide, in the seeds of diverse plants. J. Agric. Food Chem. 2016, 64, 2901-2909. [CrossRef]

11. Borgmeyer, J.R.; Smith, C.E.; Huynh, K.Q. Isolation and characterization of a $25 \mathrm{kDa}$ antifungal protein from flax seeds. Biochem. Biophys. Res. Commun. 1992, 187, 480-487. [CrossRef]

12. Wu, S.; Wang, X.; Qi, W.; Guo, Q. Bioactive protein/peptides of flaxseed: A review. Trends Food Sci. Technol. 2019, 92, 184-193. [CrossRef]

13. Tehrani, M.H.H.; Batal, R.; Kamalinejad, M.; Mahbubi, A. Extraction and purification of flaxseed proteins and studying their antibacterial activities. J. Plant Sci. 2014, 2, 70-76.

14. Okinyo-Owiti, D.P.; Dong, Q.; Ling, B.; Jadhav, P.D.; Bauer, R.; Maley, J.M.; Reaney, M.J.T.; Yang, J.; Sammynaiken, R. Evaluating the cytotoxicity of flaxseed orbitides for potential cancer treatment. Toxicol. Rep. 2015, 2, 1014-1018. [CrossRef]

15. Nwachukwu, I.D.; Aluko, R.E. Physicochemical and emulsification properties of flaxseed (Linum usitatissimum) albumin and globulin fractions. Food Chem. 2018, 255, 216-225. [CrossRef] [PubMed]

16. Kaushik, P.; Dowling, K.; McKnight, S.; Barrow, C.J.; Wang, B.; Adhikari, B. Preparation, characterization and functional properties of flax seed protein isolate. Food Chem. 2016, 197, 212-220. [CrossRef] [PubMed]

17. Tirgar, M.; Silcock, P.; Carne, A.; Birch, E.J. Effect of extraction method on functional properties of flaxseed protein concentrates. Food Chem. 2017, 215, 417-424. [CrossRef]

18. Yu, X.; Huang, S.; Nie, C.; Deng, Q.; Zhai, Y.; Shen, R. Effects of atmospheric pressure plasma jet on the physicochemical, functional, and antioxidant properties of flaxseed protein. J. Food Sci. 2020, 85, 2010-2019. [CrossRef] [PubMed]

19. Juodeikiene, G.; Zadeike, D.; Trakselyte-Rupsiene, K.; Gasauskaite, K.; Bartkiene, E.; Lele, V.; Viskelis, P.; Bernatoniene, J.; Ivanauskas, L.; Jakstas, V. Functionalisation of flaxseed proteins assisted by ultrasonication to produce coatings enriched with raspberries phytochemicals. LWT Food Sci. Technol. 2020, 124, 109180. [CrossRef]

20. Bashir, S.; Yaseen, M.; Sharma, V.; Purohit, S.R.; Barak, S.; Mudgil, D. Rheological and textural properties of gluten free cookies based on pearl millet and flaxseed. Biointerface Res. Appl. Chem. 2020, 10, 6565-6576.

21. Sanmartin, C.; Taglieri, I.; Venturi, F.; Macaluso, M.; Zinnai, A.; Tavarini, S.; Botto, A.; Serra, A.; Conte, G.; Flamini, G.; et al. Flaxseed cake as a tool for the improvement of nutraceutical and sensorial features of sourdough bread. Foods 2020, 9, 204. [CrossRef]

22. Kurt, S.; Ceylan, H.G. Effects of flaxseed and $\mathrm{pH}$ on the emulsion properties of beef by using a model system. Turk. J. Agric. Food Sci. Technol. 2018, 6, 78-83. [CrossRef] 
23. Kaur, P.; Waghmare, R.; Kumar, V.; Prasad, R.; Kaur, S.; Gat, Y. Recent advances in utilization of flaxseed as potential source for value addition. OCL 2018, 25,1-11. [CrossRef]

24. Tuncel, N.B.; Uygur, A.; Yüceer, Y.K. The effects of infrared roasting on HCN content, chemical composition and storage stability of flaxseed and flaxseed oil. J. Am. Oil Chem. Soc. 2017, 94, 877-884. [CrossRef]

25. Werner, C. Methods for roasting oilseed, and roasted oilseed products. U.S. Patent 2008/0274247 A1, 1-6 November 2008.

26. Szydłowska-Czerniak, A.; Tymczewska, A.; Momot, M.; Włodarczyk, K. Optimization of the microwave treatment of linseed for cold-pressing linseed oil-Changes in its chemical and sensory qualities. LWT Food Sci. Technol. 2020, 126, 109317. [CrossRef]

27. Wroniak, M.; Rękas, A.; Siger, A.; Janowicz, M. Microwave pretreatment effects on the changes in seeds microstructure, chemical composition and oxidative stability of rapeseed oil. LWT Food Sci. Technol. 2016, 68, 634-641. [CrossRef]

28. Waszkowiak, K.; Siger, A.; Rudzińska, M.; Bamber, W. Effect of roasting on flaxseed oil quality and stability. J. Am. Oil Chem. Soc. 2020, 97, 637-649. [CrossRef]

29. Waszkowiak, K.; Mikołajczak, B.; Kmiecik, D. Changes in oxidative stability and protein profile of flaxseeds resulting from thermal pre-treatment. J. Sci. Food Agric. 2018, 98, 5459-5469. [CrossRef]

30. Waszkowiak, K.; Mikołajczak, B.; Gliszczyńska-Świgło, A.; Niedźwiedzińska, K. Effect of thermal pre-treatment on the phenolic and protein profiles and oil oxidation dynamics of golden flaxseeds. Int. J. Food Sci. Technol. 2020, 55, 1272-1280. [CrossRef]

31. Herchi, W.; Ben Ammar, K.; Bouali, I.; Bou Abdallah, I.; Guetet, A.; Boukhchina, S. Heating effects on physicochemical characteristics and antioxidant activity of flaxseed hull oil (Linum usitatissimum $\mathrm{L}$ ). Food Sci. Technol. 2016, 36, 97-102. [CrossRef]

32. AOCS Official Method 991.43 (32.1.17). Total, soluble, and insoluble dietary fiber in foods. Enzymatic-gravimetric method, MES-TRIS buffer. In AOAC Official Methods of Analysis; AOAC International: Gaithersburg, MD, USA, 2005.

33. Kahsai, O. Methods for preparing and compositions comprising plant seed-based omega-3 fatty acids. U.S. Patent 2014/0170287 A1, 19 June 2014.

34. Waszkowiak, K.; Rudzińska, M. Effect of flaxseed meals and extracts on lipid stability in a stored meat product. J. Am. Oil Chem. Soc. 2014, 91, 979-987. [CrossRef]

35. Waszkowiak, K.; Gliszczyńska-Świgło, A.; Barthet, V.; Skręty, J. Effect of extraction method on the phenolic and cyanogenic glucoside profile of flaxseed extracts and their antioxidant capacity. J. Am. Oil Chem. Soc. 2015, 92, 1609-1619. [CrossRef] [PubMed]

36. ISO 665:2000. Oilseeds_Determination of Moisture and Volatile Matter Content (Last Reviewed in 2012); ISO: Geneva, Switzerland, 2012.

37. ISO 5983-2:2009. Animal Feeding Stuffs-Determination of Nitrogen Content and Calculation of Crude Protein Content_-Part 2: Block Digestion and Steam Distillation Method; ISO: Geneva, Switzerland, 2009.

38. ISO 659:2009. Oilseeds—Determination of Oil Content (Reference method); ISO: Geneva, Switzerland, 2009.

39. Palombo, R.; Gertler, A.; Saguy, I. A simplified method for determination of browning in dairy powders. J. Food Sci. 1984, 49, 1609-1613. [CrossRef]

40. Morales, F.J.; van Boekel, M.A.J.S. A study on advanced Maillard reaction in heated casein/sugar solutions: Colour formation. Int. Dairy J. 1998, 8, 907-915. [CrossRef]

41. Ou, B.; Hampsch-Woodill, M.; Prior, R.L. Development and validation of an improved oxygen radical absorbance capacity assay using fluorescein as the fluorescent probe. J. Agric. Food Chem. 2001, 49, 4619-4626. [CrossRef] [PubMed]

42. Waszkowiak, K.; Gliszczyńska-Świgło, A. Binary ethanol-water solvents affect phenolic profile and antioxidant capacity of flaxseed extracts. Eur. Food Res. Technol. 2016, 242, 777-786. [CrossRef]

43. Kotecka-Majchrzak, K.; Sumara, A.; Fornal, E.; Montowska, M. Proteomic analysis of oilseed cake: A comparative study of species-species proteins and peptides extracted from ten seed species. J. Sci. Food Agric. 2020, in press. [CrossRef]

44. Davis, P.J.; Williams, S.C. Protein modification by thermal processing. Allergy 1998, 53, 102-105. [CrossRef]

45. Yu, P. Protein secondary structures (a-helix and b-sheet) at a cellular level and protein fractions in relation to rumen degradation behaviours of protein: A new approach. Br. J. Nutr. 2005, 94, 655-665. [CrossRef] 
46. Liu, J.; Shim, Y.Y.; Poth, A.G.; Reaney, M.J.T. Conlinin in flaxseed (Linum usitatissimum L.) gum and its contribution to emulsification properties. Food Hydrocoll. 2016, 52, 963-971. [CrossRef]

47. Wang, H.Y.; Qian, H.; Yao, W.R. Melanoidins produced by the Maillard reaction: Structure and biological activity. Food Chem. 2011, 128, 573-584. [CrossRef]

48. Cämmerer, B.; Kroh, L.W. Shelf life of linseeds and peanuts in relation to roasting. LWT Food Sci. Technol. 2009, 42, 545-549. [CrossRef]

49. Epaminondas, P.S.; Araujo, K.L.G.V.; Nascimento, J.A.; Silva, M.C.D.; Rosenhaim, R.; Soledade, L.E.B.; Queiroz, N.; Souza, A.L.; Santos, I.M.G.; Souza, A.G. Influence of toasting and the seed variety on the physico-chemical and thermo-oxidative characteristics of the flaxseed oil. J. Therm. Anal. Calorim. 2011, 106, 545-550. [CrossRef]

50. Bekedam, E.K.; Loots, M.J.; Schols, H.A.; van Boekel, M.A.J.S.; Smit, G. Roasting effects on formation mechanisms of coffee brew melanoidins. J. Agric. Food Chem. 2008, 56, 7138-7145. [CrossRef] [PubMed]

51. Bastos, D.M.; Monaro, É.; Siguemoto, É.; Séfora, M. Maillard reaction products in processed food: Pros and cons. Food Ind. Process. Methods Equip. 2012, 15, 282-300.

(C) 2020 by the authors. Licensee MDPI, Basel, Switzerland. This article is an open access article distributed under the terms and conditions of the Creative Commons Attribution (CC BY) license (http://creativecommons.org/licenses/by/4.0/). 